\title{
Conjunctive Use of Saline and Fresh Water for Irrigating Wheat (Triticum aestivum L.) at Different Growth Stages
}

\author{
M. A. Mojid ${ }^{1}$ and A. B. M. Zahid Hossain ${ }^{2}$ \\ ${ }^{1}$ Department of Irrigation and Water Management, Bangladesh Agricultural University, \\ Mymensingh - 2202, Bangladesh \\ ${ }^{2}$ Irrigation and Water Management Division, Bangladesh Rice Research Institute, \\ Joydebpur, Gazipur \\ *Corresponding author and Email: ma_mojid@yahoo.com
}

Received: 4 September 2012

Accepted: 18 May 2013

\begin{abstract}
An experiment was conducted at the Bangladesh Agricultural University, Mymensingh during 20082009 and 2009-2010 to investigate the impacts of irrigation by saline water $\left(7 \mathrm{dS} \mathrm{m}^{-1}\right)$ at different growth stages of wheat (Triticum aestivum L.). Irrigations at crown root initiation (CRI) $\left(\mathrm{T}_{1}\right)$ or booting $\left(\mathrm{T}_{2}\right)$ or flowering $\left(\mathrm{T}_{3}\right)$ or grain filling $\left(\mathrm{T}_{4}\right)$ stage by saline water but at other growth stages by fresh water, and irrigation at all growth stages by fresh water $\left(\mathrm{T}_{5}\right.$, control) were applied. Wheat was cultivated in two consecutive years $(2008$ - 2010) under four irrigations and with recommended fertilizer doses. Irrigation water having salinity of $7 \mathrm{dS} \mathrm{m}^{-1}$ did not significantly influence plant height, spike density, spikelets per spike, 1000-grain weight, grain yield, biomass yield and harvest index. The observed diminutive variations among the treatments reflected only non harmful impacts of salinity. Irrigation water salinity, however, significantly reduced spike length and grains per spike in most cases in the first year only. Treatment $\mathrm{T}_{4}$ producing, on an average over two years, the lowest grain yield (30\% less compared to $\mathrm{T}_{5}$ ), grains per spike, spike length and spikelets per spike revealed that the grain filling stage of wheat was the most sensitive to irrigation water salinity. Although application of one of four irrigations by water of salinity $7 \mathrm{dS} \mathrm{m}^{-1}$ did not impart significant effect on wheat production, it was beneficial to avoid such irrigation at the grain filling stage.
\end{abstract}

Keywords: Wheat, growth stage, irrigation, salinity, conjunctive use

\section{Introduction}

Water scarcity is currently limiting the expansion of irrigated agriculture in many regions of the world. In many countries, fresh water is relatively scarce, but there are considerable sources of saline water, which could be utilized for irrigation if appropriate crops, soil and water management practices are established (Mantell et al., 1985; Rhoades et al., 1992). As demands on good quality water are increasing, the pressure on growers to utilize moderately saline irrigation water is also increasing (Maas et al., 1988). Although the use of saline water is a subject of increasing interest, reduction in crop yield is a major constrains. With proper management, saline water could, however, be used without adverse effects on crops and soils (Rhoades, 1984). The salt tolerance of crops depends on the type and frequency of irrigations. As the soilwater content decreases between irrigations, the concentration of salt increases. Consequently, plants are increasingly exposed to saline water with time between irrigations. If water becomes 
limiting, plants experience osmotic stress as well as matric stresses. Excessive salts present in the root zone adversely affect the plants at all growth stages (Saqib et al., 2004). The basic principle underlying a sustainable irrigation by saline water is that the salt concentration in the soil has to be kept at a relatively constant level, below a threshold value specific for each crop species (Maas and Hoffman, 1977). In order to satisfy this requirement, accurate irrigation scheduling techniques need to be used to minimize yield reductions and to optimize sustainable use of available water.

Irrigation influences dry matter production, plant height, leaf area, duration of grain filling and protein content of wheat grain (Razzaque et al., 1992; Thomson and Chase, 1992). Due to scarcity of water, only $42.78 \%$ of the total wheat area in Bangladesh is irrigated and the rest is cultivated under rainfed condition (BBS, 1998). Over $30 \%$ of the net cultivable area in Bangladesh exists in coastal regions, where fresh water is becoming scarce with time. Cultivation of winter crops, including wheat, is very limited in the coastal area due to inadequate fresh irrigation water and accumulation of salts in the surface soil.

Salinity inhibits germination (Bernerdo et al., 2000a), leaf cell expansion and ultimate leaf growth (Cramer et al., 2001), leaf area and dry mater accumulation, rate of net $\mathrm{CO}_{2}$ assimilation, and relative growth (Bernerdo et al., 2000b) of wheat. The effect of water salinity on the yield of wheat has been studied by a number of investigators; most of whom conducted their experiments on salt sensitivity by applying saline water during the entire growing season. However, the sensitivity of crops to salinity often changes from one stage of growth to the other. Maas and Poss (1989) irrigated two wheat species (Triticum aestivum L., cv. Probred and Triticum turgidum L., Durum Group, cv. Aldura) by saline waters with seven salinity levels ranging from 1.4 to $28 \mathrm{dS} \mathrm{m}$ m $^{-1}$ at vegetative, reproductive and maturation stages. In their experiments, the grain yields from the plants stressed during either the vegetative, reproductive or maturation stages indicated that both species became less sensitive to salinity at the later stages of plant growth. Francois et al. (1994), on the other hand, irrigated wheat by water with salinity of 1.4, 10.0, 20.0 and $30.0 \mathrm{dS}$ $\mathrm{m}^{-1}$ in one year, and 1.4, 8.0, 16.0 and $24.0 \mathrm{dS}$ $\mathrm{m}^{-1}$ in the next year. The effect of salinity in their experiments appeared to be most pronounced on the yield components that developed at the time the salt stress was imposed. However, they maintained the total grain yields by substituting moderately saline irrigation waters for fresh water during parts of the season.

A sensible use of saline water requires a better understanding of how plants respond to salinity at different growth stages (Maas et al., 1988). One way for doing this is to identify the salt sensitive stage(s) and applying irrigation at the sensitive stage(s) by fresh water and by saline water (up to the tolerant limit). Keeping this idea in view, this study was undertaken: (i) to identify the salt sensitive stage(s) of wheat, and (ii) to compare the effects of irrigation on yield and yield contributing attributes by saline water at different growth stages of wheat.

\section{Materials and Methods}

\subsection{Site and climate}

Experiments with wheat (Triticum aestivum L.) were conducted at the experimental farm of the Bangladesh Agricultural University, Mymensingh during December to March of 2008-2009 and 2009-2010 (hereafter referred to year I and year II, respectively). The experimental site was in the Agro-Ecological Zone (AEZ) 9 that lies at $24.75^{\circ} \mathrm{N}$ latitude and $90.50^{\circ} \mathrm{E}$ longitude. Soil samples were collected before setting up the experiments using a hand auger from five spots that represented the experimental field. The samples were collected at $20 \mathrm{~cm}$ increments to a depth of $60 \mathrm{~cm}$ to determine the major physico-chemical properties of soil. Silt loam underlying sandy loam soils in 
the field belongs to the Old Brahmaputra floodplain (BARC, 2005). Table 1 gives the texture, bulk density and field capacity water content of the soils at different layers of the experimental field. The top soil $(0-60 \mathrm{~cm})$ had $0.49 \%$ organic carbon $(0.85 \%$ organic matter), $6.9 \mathrm{pH}(1: 2.5=$ soil : water $), 0.04 \%$ total nitrogen, 17 and $9.9 \mathrm{ppm}$ available phosphorus and sulphur, respectively, 25.5, 8.4 and 691.0 ppm exchangeable potassium, sodium and calcium, respectively, 45.0 and $18.4 \%\left(\mathrm{v} \mathrm{v}^{-3}\right)$ field capacity and permanent wilting point, respectively, $1.33 \mathrm{~g} \mathrm{~cm}^{-3}$ bulk density and 0.62 $\mathrm{dS} \mathrm{m}{ }^{-1}$ electrical conductivity (EC) of saturation extract. The daily maximum temperature during December to March varied from 24.9 to $30.9^{\circ} \mathrm{C}$ in $2008-2009$ and from 24.0 to $32.0^{\circ} \mathrm{C}$ in 2009 - 2010. The daily minimum temperature during that period varied from 13.5 to $19.0^{\circ} \mathrm{C}$ in $2008-$ 2009 and from 11.7 to $20.7^{\circ} \mathrm{C}$ in $2009-2010$. There was no rainfall during the two wheatgrowing seasons in this study.

\subsection{Treatments and experimental design}

There were five irrigation treatments: $T_{1}=$ irrigation by saline water at CRI stage and fresh water at other stages, $\mathrm{T}_{2}=$ irrigation by saline water at booting stage and fresh water at other stages, $\mathrm{T}_{3}=$ irrigation by saline water at flowering stage and fresh water at other stages, $\mathrm{T}_{4}=$ irrigation by saline water at grain filling stage and fresh water at other stages, and $\mathrm{T}_{5}=$ irrigation by fresh water at all growth stages (control). The experiment was laid out in a Randomized Complete Block Design (RCBD) with three replications. The unit plots were of 3 $\mathrm{m} \times 2 \mathrm{~m}$ size. A buffer zone of $1 \mathrm{~m}$ both between the adjacent blocks and adjacent plots was retained to minimize the interference effects of the treatments and replications among the plots. Levees of appropriate size were constructed around the plots to retain irrigation water. Recommended doses of urea, triple super phosphate, muriate of potash and gypsum (at $260,160,110$ and $110 \mathrm{~kg} \mathrm{ha}^{-1}$, respectively) were applied. Two-thirds of urea and the entire doses of the other fertilizers were applied as a basal dose. The remaining urea was top-dressed before first irrigation. At good tilth condition of the soil, 2 to $3-\mathrm{cm}$ deep furrows, with a spacing of $20 \mathrm{~cm}$, were made with hand rakes. Wheat seeds (cv: Shatabdi) were sown in the furrows @ $120 \mathrm{~kg} \mathrm{ha}^{-1}$ on 6 December 2008 (year I) and on 14 December 2009 (year II). Soil-water contents in the plots were measured at sowing with a Trime FM moisture meter (Eijkelkamp, The Netherlands). In order to control insect pests, Bavistine (@0.9 $0.9 \mathrm{~kg}^{-1}$ ) and Ridomil Gold (1 $\mathrm{kg} \mathrm{ha}^{-1}$ ) were sprayed before first irrigation.

\subsection{Application of irrigations}

Saline water was prepared at a constant salinity level of $7 \mathrm{dS} \mathrm{m}^{-1}$ at $25^{\circ} \mathrm{C}$. To maintain this salinity level, sodium chloride (table salt) @ $5.082 \mathrm{~g} \mathrm{~L} \mathrm{~L}^{-1}$ was mixed with groundwater pumped with a deep tubewell in a pit lined with polyethylene sheet. The EC of groundwater was $0.39 \mathrm{dS} \mathrm{m}{ }^{-1}$. The salt concentration of $5.082 \mathrm{~g}$ $\mathrm{L}^{-1}$ was determined in laboratory calibration to attain the required water salinity of $7 \mathrm{dS} \mathrm{m}$. Wheat was irrigated following a schedule that was based on crop-water requirement and soilwater content. Field capacity was determined in laboratory on soil samples collected from the plots and the values were cross-checked by insitu measurements in the field. Four irrigations were applied to the crop both in year I and year II experiments. Soil-water content in the plots was measured with a Trime FM moisture meter before applying the irrigations. The quantity of water required to bring soil water to the field capacity was calculated for each plot for an effective root zone depth of $60 \mathrm{~cm}$. The first irrigation was applied at 19 and 21 days after sowing (DAS) in year I and year II, respectively. The second, third and fourth irrigations were applied at 51, 67 and 86 DAS, respectively in year I and at 37, 55 and 80 DAS, respectively in year II. An equal amount of water $(2.17 \mathrm{~cm})$ was applied to all plots, in a particular irrigation in year I. In year II, each of the first and second irrigations consisted of $2.5 \mathrm{~cm}$ water while each of the third and fourth irrigations consisted of 4 $\mathrm{cm}$ water. 
Table 1. Particle size distribution, texture, bulk density and field capacity water content of soil at different layers of the experimental field (The same field was used in the two years' experiment)

\begin{tabular}{cccclcc}
\hline \multirow{2}{*}{$\begin{array}{c}\text { Soil depth } \\
(\mathrm{cm})\end{array}$} & \multicolumn{2}{c}{ Particle size distribution (\%) } & Textural class & $\begin{array}{c}\text { Bulk density } \\
\left(\mathrm{g} \mathrm{cm}^{-3}\right)\end{array}$ & $\begin{array}{c}\text { Field capacity } \\
\left(\% \mathrm{v} \mathrm{v} \mathrm{v}^{-1}\right)\end{array}$ \\
\cline { 2 - 4 } & Sand & Silt & Clay & & 1.26 & 39.10 \\
\hline $0-20$ & 32.58 & 56.66 & 10.76 & Silt loam & 1.35 & 38.62 \\
$20-40$ & 54.57 & 40.0 & 5.43 & Sandy loam & 1.35 \\
$40-60$ & 67.91 & 26.67 & 5.42 & Sandy loam & 1.40 & 36.85 \\
\hline
\end{tabular}

\subsection{Measurements}

At physiological maturity, a harvest area of $1 \mathrm{~m}$ $\times 1 \mathrm{~m}$ was selected in the middle of each plot. Also, the crop of the remaining portion of each plot was harvested. After recording data on plant height and length of spike, the plant materials were dried in sun. Grain, straw and biomass yields were recorded. Variation of root development of the plants due to salinity was assessed by sampling roots from $20 \mathrm{~cm} \times 30 \mathrm{~cm}$ area in $0-20,20-40$ and $40-60 \mathrm{~cm}$ soil profiles soon after harvesting the crop. The roots were separated by washing out the soils and dried in an oven at $75^{\circ} \mathrm{C}$ for $60 \mathrm{~h}$ to obtain their dry mass. Root-density was calculated by dividing dry weight of the root sample by the sampling area.

The harvest index was calculated as the ratio of grain yield to biomass yield (Gardner et al., 1985). Water-productivity of wheat was determined by dividing the grain yield by the quantity of water used by the crop, and also by dividing the quantity of water used by the crop by the grain yield. The water used by the crop included the applied irrigation water and change in soil-water content between sowing and harvesting of the crop. Analysis of variance was done for the Randomized Complete Block Design (RCBD, 1 factor). The R-package Agricolae (De Mendiburu, 2010) was used for the analysis.

\section{Results and Discussion}

\subsection{Growth attributes}

Plant height varied from $88.4 \mathrm{~cm}$ in treatment $\mathrm{T}_{4}$ to $94.8 \mathrm{~cm}$ in $\mathrm{T}_{2}$ in year $\mathrm{I}$ and from $94.4 \mathrm{~cm}$ in $\mathrm{T}_{1}$ to $95.8 \mathrm{~cm}$ in $\mathrm{T}_{5}$ in year II (Table 2). The variations in plant height among the treatments were, however, insignificant $(p=0.05)$. It was revealed that irrigation water of salinity 7 $\mathrm{dS} \mathrm{m}^{-1}$, applied at the CRI stage, reduced plant height considerably. Because of reduced tillering in year II, spike density was lower in that year than in year I. In an experiment with wheat where all irrigations were applied by saline water of 3.5 and $6.9 \mathrm{dS} \mathrm{m}^{-1}$, Poustini (1995) obtained reduced number of tillers having spikes and reduced relative growth rate. A leaf area index (LAI) of 2.9, 3.1, 2.8, 3.1 and 2.5 in treatment $\mathrm{T}_{1}, \mathrm{~T}_{2}, \mathrm{~T}_{3}, \mathrm{~T}_{4}$ and $\mathrm{T}_{5}$, respectively (measured in year II only) did not show considerable impact of irrigation water salinity at any particular stage of wheat growth.

Spike length responded significantly to irrigation water salinity imposed at different growth stages in year I only. Treatment $\mathrm{T}_{2}$ provided the largest spike length $(9.41 \mathrm{~cm})$, while $\mathrm{T}_{4}$ provided the smallest $(8.48 \mathrm{~cm})$ value in year $\mathrm{I}$. The second lowest spike length $(8.84 \mathrm{~cm})$, obtained in $T_{1}$, implied that reduction in spike length in this treatment was due to extraneous effects since the spike attained their full length before the grain filling stage. The spike length decreased by 5.8 , 2.9 and $9.6 \%$ in $\mathrm{T}_{1}, \mathrm{~T}_{3}$ and $\mathrm{T}_{4}$, respectively compared to that in $\mathrm{T}_{5}$. 
Table 2. Growth attributes of wheat under five irrigation treatments for 2008-2009 (year I) and 2009 2010 (year II) crop periods

\begin{tabular}{llcccc}
\hline Year & Treatment & $\begin{array}{c}\text { Plant height } \\
(\mathrm{cm})\end{array}$ & $\begin{array}{c}\text { Spike }{ }^{-2} \\
(\text { no. })\end{array}$ & $\begin{array}{c}\text { Spike length } \\
(\mathrm{cm})\end{array}$ & $\begin{array}{c}\text { Spikelet spike }^{-1} \\
(\text { no. })\end{array}$ \\
\hline \multirow{4}{*}{ Year I } & $\mathrm{T}_{1}$ & $90.33^{\mathrm{a}}$ & $338.0^{\mathrm{a}}$ & $8.837^{\mathrm{ab}}$ & $18.97^{\mathrm{a}}$ \\
& $\mathrm{T}_{2}$ & $94.80^{\mathrm{a}}$ & $328.7^{\mathrm{a}}$ & $9.410^{\mathrm{a}}$ & $19.80^{\mathrm{a}}$ \\
& $\mathrm{T}_{3}$ & $91.20^{\mathrm{a}}$ & $334.7^{\mathrm{a}}$ & $9.103^{\mathrm{ab}}$ & $18.87^{\mathrm{a}}$ \\
& $\mathrm{T}_{4}$ & $88.40^{\mathrm{a}}$ & $350.0^{\mathrm{a}}$ & $8.477^{\mathrm{b}}$ & $17.20^{\mathrm{a}}$ \\
& $\mathrm{T}_{5}$ & $90.37^{\mathrm{a}}$ & $349.3^{\mathrm{a}}$ & $9.377^{\mathrm{ab}}$ & $19.43^{\mathrm{a}}$ \\
& $\mathrm{HSD}_{0.05}$ & 9.928 & 95.17 & 0.916 & 3.325 \\
\hline \multirow{3}{*}{ Year II } & $\mathrm{T}_{1}$ & $94.37^{\mathrm{a}}$ & $326.3^{\mathrm{a}}$ & $9.633^{\mathrm{a}}$ & $17.13^{\mathrm{a}}$ \\
& $\mathrm{T}_{2}$ & $95.13^{\mathrm{a}}$ & $315.0^{\mathrm{a}}$ & $9.267^{\mathrm{a}}$ & $16.63^{\mathrm{a}}$ \\
& $\mathrm{T}_{3}$ & $95.03^{\mathrm{a}}$ & $332.0^{\mathrm{a}}$ & $9.767^{\mathrm{a}}$ & $16.83^{\mathrm{a}}$ \\
& $\mathrm{T}_{4}$ & $95.37^{\mathrm{a}}$ & $333.7^{\mathrm{a}}$ & $9.667^{\mathrm{a}}$ & $17.23^{\mathrm{a}}$ \\
& $\mathrm{T}_{5}$ & $95.80^{\mathrm{a}}$ & $290.0^{\mathrm{a}}$ & $9.567^{\mathrm{a}}$ & $17.70^{\mathrm{a}}$ \\
& $\mathrm{HSD}_{0.05}$ & 8.067 & 118.1 & 0.913 & 1.563 \\
\hline
\end{tabular}

Common letter(s) within the same column do not differ significantly at $5 \%$ level of significance analyzed by Tukey.

The irrigation water salinity imposed at different growth stages of wheat exerted insignificant impact on the number of spikelets per spike in both crop years. In year $\mathrm{I}, \mathrm{T}_{5}$ produced the highest number of spikelets per spike (19.43) and $\mathrm{T}_{4}$ provided the lowest value. In year II, however, $\mathrm{T}_{5}$ and $\mathrm{T}_{2}$ produced the equivalent number of spikelets per spike. From the two years' mean, the highest number of spikelets per spike (19) was obtained in $\mathrm{T}_{5}$, and an average of $2.8,1.9,3.9$ and $7.3 \%$ decrease in the number of spikelets per spike was obtained in $T_{1}, T_{2}, T_{3}$ and $\mathrm{T}_{4}$, respectively compared to the control. The lowest number of spikelets per spike (17), counted in $\mathrm{T}_{4}$, did not, however, indicate any negative impact of irrigation water salinity since the spikelets were formed before application of this irrigation. Also, since the number of spikelets per spike is a function of spike length, the longest spike (in $\mathrm{T}_{5}$ ) resulted in the largest number of spikelets per spike. Saline water retarded root growth. The mean root densities at harvest were $0.46,0.50,0.41,0.48$ and $0.52 \mathrm{~kg}$ $\mathrm{m}^{-2}$ (of surface area) in $\mathrm{T}_{1}, \mathrm{~T}_{2}, \mathrm{~T}_{3}, \mathrm{~T}_{4}$ and $\mathrm{T}_{5}$, respectively. The root density was the maximum when irrigation was applied by fresh water at all growth stages $\left(\mathrm{T}_{5}\right)$. The second highest root density was in $\mathrm{T}_{2}$. Saline water at flowering stage $\left(T_{3}\right)$ retarded further development of roots but salinity imposed after flowering did not reduce root growth. 


\subsection{Yield attributes and yield}

Number of grains per spike varied between the treatments, significantly in year I but insignificantly in year II (Table 3). The highest number of grains per spike was produced when all irrigations were applied by fresh water $\left(\mathrm{T}_{5}\right)$ in both crop years. The lowest number of grains per spike in $\mathrm{T}_{4}$ in year I implied that irrigation water salinity at grain filling stage was the most sensitive to grain formation. The 1000-grain weight of wheat in the treatments remained unaffected by the salinity of irrigation water at different growth stages in both the years.

Table 3. Yield attributes of wheat under five irrigation treatments for 2008-2009 (year I) and 2009 2010 (year II) crop periods

\begin{tabular}{|c|c|c|c|c|c|c|}
\hline Year & Treatment & $\begin{array}{l}\text { Grains } \\
\text { spike }^{-1} \\
\text { (no.) }\end{array}$ & $\begin{array}{c}\text { 1000-grain } \\
\text { weight } \\
\text { (g) }\end{array}$ & $\begin{array}{l}\text { Grain yield } \\
\quad\left(\mathrm{t} \mathrm{ha}^{-1}\right)\end{array}$ & $\begin{array}{c}\text { Biological } \\
\text { yield } \\
\left(\mathrm{t} \mathrm{ha}^{-1}\right)\end{array}$ & $\begin{array}{c}\text { Harvest } \\
\text { index } \\
\text { (fraction) }\end{array}$ \\
\hline \multirow{6}{*}{ Year I } & $\mathrm{T}_{1}$ & $29.73^{\mathrm{ab}}$ & $45.73^{\mathrm{a}}$ & $2.470^{\mathrm{a}}$ & $11.20^{\mathrm{a}}$ & $0.217^{\mathrm{a}}$ \\
\hline & $\mathrm{T}_{2}$ & $37.90^{\mathrm{ab}}$ & $43.25^{\mathrm{a}}$ & $2.940^{\mathrm{a}}$ & $13.07^{\mathrm{a}}$ & $0.223^{\mathrm{a}}$ \\
\hline & $\mathrm{T}_{3}$ & $28.37^{\mathrm{ab}}$ & $44.08^{\mathrm{a}}$ & $2.663^{\mathrm{a}}$ & $11.73^{\mathrm{a}}$ & $0.227^{\mathrm{a}}$ \\
\hline & $\mathrm{T}_{4}$ & $24.60^{\mathrm{b}}$ & $45.26^{\mathrm{a}}$ & $2.333^{\mathrm{a}}$ & $12.27^{\mathrm{a}}$ & $0.193^{\mathrm{a}}$ \\
\hline & $\mathrm{T}_{5}$ & $40.40^{\mathrm{a}}$ & $39.17^{\mathrm{a}}$ & $3.173^{\mathrm{a}}$ & $12.47^{\mathrm{a}}$ & $0.257^{\mathrm{a}}$ \\
\hline & $\mathrm{HSD}_{0.05}$ & 14.08 & 8.466 & 1.27 & 3.785 & 0.099 \\
\hline \multirow{6}{*}{$\begin{array}{l}\text { Year } \\
\text { II }\end{array}$} & $\mathrm{T}_{1}$ & $33.30^{\mathrm{a}}$ & $45.47^{\mathrm{a}}$ & $2.300^{\mathrm{a}}$ & $7.833^{\mathrm{a}}$ & $0.291^{\mathrm{a}}$ \\
\hline & $\mathrm{T}_{2}$ & $30.43^{\mathrm{a}}$ & $45.58^{\mathrm{a}}$ & $2.067^{\mathrm{a}}$ & $7.600^{\mathrm{a}}$ & $0.252^{\mathrm{a}}$ \\
\hline & $\mathrm{T}_{3}$ & $30.90^{\mathrm{a}}$ & $46.18^{\mathrm{a}}$ & $1.700^{\mathrm{a}}$ & $7.233^{\mathrm{a}}$ & $0.214^{\mathrm{a}}$ \\
\hline & $\mathrm{T}_{4}$ & $32.63^{\mathrm{a}}$ & $46.84^{\mathrm{a}}$ & $1.967^{\mathrm{a}}$ & $7.667^{\mathrm{a}}$ & $0.242^{\mathrm{a}}$ \\
\hline & $\mathrm{T}_{5}$ & $37.63^{\mathrm{a}}$ & $42.73^{\mathrm{a}}$ & $2.967^{\mathrm{a}}$ & $8.133^{\mathrm{a}}$ & $0.366^{\mathrm{a}}$ \\
\hline & $\mathrm{HSD}_{0.05}$ & 13.405 & 10.749 & 3.571 & 3.582 & 0.376 \\
\hline
\end{tabular}

Common letter(s) within the same column do not differ significantly at $5 \%$ level of significance analyzed by Tukey. 
There was no significant difference in grain yield of wheat among the treatments. The highest grain yields of $3.17 \mathrm{t} \mathrm{ha}^{-1}$ in year I and $2.97 \mathrm{t}$ $\mathrm{ha}^{-1}$ in year II were obtained when fresh water irrigation was applied at all growth stages. The lowest grain yield was in $T_{4}$ in year $I$ and in $T_{3}$ in year II. Irrigation by saline water at CRI, booting, flowering and grain filling stages reduced the grain yield, on an average over years, by $22,18,29$ and $30 \%$, respectively compared to the control. So, irrigation water salinity at flowering and grain filling stages was, although not significant, sensitive enough in reducing grain yield. These results are similar to that of Poustini (1995) who found no effect of irrigation water salinity of 3.5 and $6.9 \mathrm{dS} \mathrm{m}^{-1}$ on net assimilation rate. The results obtained from the experiments are also in agreement with that of Phogat et al. (2001) who reported that wheat could tolerate salinity levels up to $6 \mathrm{dS} \mathrm{m}^{-1}$ and there was no significant reduction in grain yield with two irrigations by water of salinity $6.5 \mathrm{dS}$ $\mathrm{m}^{-1}$. It is noted that the lower grain yield in year II than in year I was due to smaller spike density in year II. Irrigation by saline water at different growth stages did not significantly influence biomass yield of wheat. From the mean biomass yields of the two crop years, it was observed that irrigation water salinity was influential at CRI $\left(\mathrm{T}_{1}\right)$ and flowering $\left(\mathrm{T}_{3}\right)$ stages in reducing biomass yield. Harvest index of wheat (Table 3) remained impervious by the salinity of irrigation water at different growth stages; the small variations obtained were insignificant. Treatment $\mathrm{T}_{5}$ always resulted in the highest harvest index. The lowest harvest index was in $\mathrm{T}_{4}$ in year I and in $\mathrm{T}_{3}$ in year II. This implied that irrigation water salinity influenced harvest index when applied at the flowering and grain filling stages.

Table 4. Components of water requirement and water productivity of wheat for grain production in different treatments during 2008-2009 (year I) and 2009-2010 (year II) crop periods

\begin{tabular}{cccccccc}
\hline Year & Treatment & $\begin{array}{c}\text { Irrigation } \\
(\mathrm{cm})\end{array}$ & $\begin{array}{c}\text { Soil } \\
\text { water } \\
\text { deficit } \\
(\mathrm{cm})\end{array}$ & $\begin{array}{c}\text { Total } \\
\text { water } \\
\text { used } \\
(\mathrm{cm})\end{array}$ & $\begin{array}{c}\text { Yield } \\
(\mathrm{kg} \\
\left.\mathrm{ha}^{-1}\right)\end{array}$ & $\begin{array}{c}\text { Water } \\
\text { productivity } \\
\left(\mathrm{kg} \mathrm{ha}^{-1} \mathrm{~cm}^{-1}\right)\end{array}$ & $\begin{array}{c}\text { Water } \\
\text { productivity } \\
\left(\mathrm{L} \mathrm{kg}^{-1}\right)\end{array}$ \\
\hline \multirow{2}{*}{ Year I } & $\mathrm{T}_{3}$ & 8.67 & 2.82 & 11.49 & 2470 & 215 & 465 \\
& $\mathrm{~T}_{2}$ & 8.67 & 3.84 & 12.51 & 2940 & 235 & 426 \\
& $\mathrm{~T}_{4}$ & 8.67 & 2.94 & 11.61 & 2663 & 229 & 436 \\
& $\mathrm{~T}_{5}$ & 8.67 & 2.22 & 10.89 & 2333 & 214 & 467 \\
\hline & $\mathrm{T}_{1}$ & 13.00 & 3.51 & 16.51 & 2300 & 139 & 718 \\
& $\mathrm{~T}_{2}$ & 13.00 & 3.69 & 16.69 & 2067 & 124 & 807 \\
Year II & $\mathrm{T}_{3}$ & 13.00 & 2.99 & 15.99 & 1700 & 106 & 941 \\
& $\mathrm{~T}_{4}$ & 13.00 & 4.10 & 17.10 & 1967 & 115 & 869 \\
& $\mathrm{~T}_{5}$ & 13.00 & 3.74 & 16.74 & 2967 & 177 & 564 \\
\hline
\end{tabular}




\subsection{Water productivity of wheat}

Total water used by wheat and water productivity of the crop under different irrigation treatments are given in Table 4. Treatment $\mathrm{T}_{5}$ produced the highest water productivity for grain production $\left(278 \mathrm{~kg} \mathrm{ha}^{-1} \mathrm{~cm}^{-1}\right.$ in year I and $177 \mathrm{~kg}$ $\mathrm{ha}^{-1} \mathrm{~cm}^{-1}$ in year II). The crop-water productivity decreased by $23,15,18$ and $23 \%$ in $\mathrm{T}_{1}, \mathrm{~T}_{2}, \mathrm{~T}_{3}$ and $T_{4}$, respectively compared to $T_{5}$ in year $I$. The corresponding decrease in water productivity in year II was $21,30,40$ and $35 \%$. Total water used by the crop remained mostly stable in different treatments in a year, but because of the reduction in grain yield due to the effect of irrigation water salinity at different growth stages, the water productivity of wheat decreased. Consequently, the water requirement per kilogram of wheat production increased.

\section{Conclusions}

The grain filling stage of wheat was the most sensitive to the salinity of irrigation water $(7 \mathrm{dS}$ $\mathrm{m}^{-1}$ ). Irrigation by saline water at this stage reduced grain yield by $30 \%$. The booting stage was the most salt-tolerant and also salt-loving. Saline water at this stage augmented plant height, spikelets per spike, and grain and biomass yields compared to the control treatment. The order of salt sensitive stages was: grain filling stage> CRI stage > flowering stage> booting stage. It may be concluded that the wheat variety under this study can be irrigated by saline water $\left(\leq 7 \mathrm{dS} \mathrm{m}^{-1}\right)$ without any significant yield loss, especially if irrigation is applied during the booting and flowering stages. When fresh water is not available or is difficult to obtain, saline water, if available, can be used conjunctively with fresh water for irrigating wheat at less sensitive growth stages. Further studies are needed in coastal saline areas for expansion of wheat cultivation in moderate saline zones in Bangladesh.

\section{References}

BARC (Bangladesh Agricultural Research Council). 2005. Soil fertility status of different agro-ecological zones. BARC Soils Publication, No. 45:15-32.

BBS (Bangladesh Bureau of Statistics). 1998. Statistical Year Book of Bangladesh. Bangladesh Bureau of Statistics, Statistics Division, Ministry of Planning, Government of the People's Republic of Bangladesh, $144 \mathrm{p}$.

Bernerdo, F. A., Dieguez, E. T., Cortes, A. L., Ojanguren, C. L. T., Jones, H. G. and Chairez, F. A. 2000b. Path analysis of cowpea early seedling growth under saline conditions. International Journal of Experimental Botany, 67:85-92.

Bernerdo, F. A., Dieguez, E. T., Jones, H. G., Chairez, F. A., Ojanguren, C. L. T. and Cortes, A. L. 2000a. Screening and classification of cowpea genotypes for salt tolerance during germination. International Journal of Experimental Botany, 67:71-84.

Cramer, G. R., Schmidt, C. L. and Bidrat, C. 2001. Analysis of cell wall hardening and cell wall enzymes of salt-stressed maize (Zea mays) leaves. Australian Journal of Plant Physiology, 28:101-109.

De Mendiburu, F. 2010. Agricolae: Statistical Procedures for Agricultural Research using R. [Online] Universidad Agraria La Molina and Centro International de la Papa. Peru. [Accessed 10 December 2010; Available from http://tarwi.lamolina.edu.pe/ fmendiburu/ ].

Francois, L. E., Grieve, C. M., Maas, E. V. and Lesch, S. M. 1994. Time of salt stress affects growth and yield components of irrigated wheat. Agronomy journal, 86:100-107. 
Gardner, F. P., Peacrce, R. B. and Mitchell, R. L. 1985. Physiology of Crop Plants. Iowa State Univ. Press, Iowa 66.

Maas, E. V. and Hoffman, G. J. 1977. Crop salt tolerance - current assessment. Journal of the Irrigation and Drainage Division, ASCE 103(IR2):115-134.

Maas, E. V. and Poss, J. A. 1989. Salt sensitivity of wheat at various growth stages. Irrigation Science, 10:29-40.

Maas, E. V., Donovan, T. J. and Francois, L. E. 1988. Salt tolerance of irrigated guayule. Irrigation Science, 9:199-211.

Mantell, A., Srenlel, H. and Meiri, A. 1985. Drip irrigation of cotton with saline-sodic water. Irrigation Science, 6:95-106.

Phogat, V., Satyawan, S., Kumar, S., Sharma, S. K., Kapoor, A. K. and Kuhal, M. S. 2001. Performance of upland cotton and wheat genotypes under different saline conditions. Indian Journal of Agricultural Sciences, 71:303-305.

Poustini, K. 1995. Physiological responses of two wheat cultivars to salinity stress. Iranian Journal of Agricultural Sciences, 26:57-64.
Razzaque, M. A., Suffiun, M. A., and Badruddin, M. 1992. Wheat in national economy in Bangladesh. Adv. Crop Sci. Proc. First Biennial Conference CSSB, 18-20 January, 1992, 13-26 pp.

Rhoades, J. D. 1984. New strategy for irrigation. Proceedings, ASCE, Irrigation and Drainage, Special Conference on Water Today and Tomorrow, July 24-26, 1984, Flagstaff, Arizona, 231 p.

Rhoades, J. D., Kandiah, A. and Mashali, A. N. 1992. The use of saline water for crop production. FAO Irrigation and Drainage Paper. FAO (Food and Agriculture Organization) of the United Nations, Rome, 48 p.

Saqib, M., Akhtar, J. and Qureshi, R. H. 2004. Pot study on wheat growth in saline and water logged compact soil. Soil and Tillage Research, 77:169-177.

Thomson, J. A. and Chase, D. L. 1992. Effect of limited irrigation on growth and yield of some dwarf wheat in southern New South Wales. Australian Journal of Experimental Agriculture, 32:725-730. 